\title{
Toponyms and Identity of Canggal Temple Area in Eco-linguistics Perspective
}

\author{
Niken Wirasanti \\ Department of Archeology, Faculty of Cultural Sciences, University of Gadjah Mada \\ Yogyakarta, Indonesia \\ wirasanti.niken@gmail.com
}

\begin{abstract}
Naming a place (toponym) is a reflection of settlement area which is embodied in the language. Toponyms based on physical environment, biological, and cultural represents the interrelation between language and the environment. Exploring toponyms of a certain area can explain a lot of things such as the history of the settlement that reflects the identity of the people around it. This paper describes the toponyms of Canggal Temple area of Gendol hills, Magelang, Central Java, which is based on the environmental elements of biological elements, non-biological elements, and charismatic figures. The research problem was to trace the toponyms transition that originally used Sanskrit to name a certain place in the eighth century with the background of Hinduism culture, and its continuation using the local Javanese language with the background of the Islamic religion. This Research used the ecolinguistic approach by examining the language (toponyms) in the context of the cultural environment. Data were obtained from Canggal Inscription (732 AD), and the toponyms of village or hamlet names around the temple; the cultural transformation was, then, analyzed. The study results could be explained from the cultural transformation that occurred in the area of Canggal Temple associated with the socio-cultural life of society.
\end{abstract}

Keywords - identity; environment; Canggal temple; toponym; eco-linguistics; transformation

\section{INTRODUCTION}

The name of a place (toponym) is a cultural product that describes the interaction of a certain community with the environment. Environment becomes a source of knowledge for the community embodied in the language. Giving the name of a certain location of settlements referred to geographic phenomena and socio-cultural events that happened at that time. The place names have a conventional character using language that expresses a typical affixation of real conditions of an environment. It is interesting to explore because there are grounds for granting a toponym associated with ideas and socio-cultural community.

The history of the ancient Mataram kingdom is frequently associated with Canggal inscription. Besides the temples, the evidence of the inscription indicates that the kingdom began to stand when King Sanjaya marked the victory over his enemies by setting up a lingga in Sthirangga Hill (Gendol Hills region) in the year of 732 AD. The name of the first king, Sanjaya had not been mentioned on Canggal inscription. Based on the Manyasih inscriptions (907 AD), it was mentioned that Sanjaya was the first king reigning Medang. The name, Medang, is interesting because at this time in the region, there was a toponym village called Medangan, thus, there were arguments suggested that Medang was situated not far from the hills of Gendol (Munoz 2009; Poesponegoro, et al. 2009; Wirasanti, 2015 \& 2016)

Sanskrit inscription indicates the acculturation happened between local culture and Indian culture at that period. Sedyawati (1995) argues that the intensity of acculturation between Indian culture and the Archipelago culture occurred in Kedu region in VIII-X century AD. The argument can be proven by the temples, and statues spread around Kedu region (Central Java), including Canggal Temple area. Archaeological finds, including statues, were found scattered on the plains, while the remaining was built at the top of Gendol Hills area such as the temples located on the top of Wukir hill (Canggal Temple), Sari Hill, Mantingan Hill, Bobosan Hill, and Pring Hill which are still viewable.

Civilization in Canggal Temple area continued until Islam entered in the area. However, it is not easy to know the process of cultural change that occurred in the region. The evidence that can be traced is the place names using Javanese language (local) written in Arabic language background such as on the graves of Islam religious leaders (mullahs) who lived in that place.

Research on reconstructing cultural changes based on toponym in inscription and ecolingustic approach is understudied. Therefore, this study takes this gab to explore toponym changes illustrating cultural transformation in community from hinduism cultural to muslim society.

\section{METHOD}

This study used descriptive qualitative method. Descriptive methods exercised for exposing the toponyms in Hindu period and Islamic period based on inscriptions and data collection. Next, conducted signifier and signified categorization of toponyms. The analysis was carried out by language axis technique (Saussure and Barthes) that was paradigmatig and sintagmatig arranged in table. The structure of the sign indicated the concept of sacred space. Then, based on the sign structure analysis, changes in surface structure appeared while the meaning remained the same. 


\section{RESUlT AND DISCUSSION}

The features of Gendol hills area are a series of hills, some of which are separated hills. Among the series of hills, there is a broad and fertile land marked by a number of springs. There are also some rivers that flow around the hills such as Blongkeng River, Putih River and their tributaries are tipped at Merapi Vulcano (Wirasanti, 2016). Canggal Temple area is an area located in the complex of Gendol Hills, Magelang, Central Java. Canggal Temple which was built in Bukit Wukir proven by Canggal inscription (732 AD) stated the worshipping on Siva along with Vishnu and Brahma, so it can be interpreted that at that time King Sanjaya and his people embraced Hinduism.

Canggal inscription mentions King Sanjaya established a lingga on the hill Sthiranga in the region of Kunjarakunja. Sthirangga means sturdy that denotatively means that Gendol Hills (Wukir Hill) is an igneous rock formed by magmatic processes which are much older than sediments of the ancient Merapi and has Quaternary age. As it can be interpreted figuratively, Sthirangga lingga in the hills is a milestone of the victory of Sanjaya who managed to defeat his enemies.

In Canggal inscription, it is also mentioned Kunjarakunja which can be interpreted Kunjara = elephant and Kunja = place covered by ivy. Poerbotjaraka interprets the word Kunjarakunja as the elephant forest or forests where elephants live. This opinion is now being doubtful. Kunjarakunja word can also mean the forest of ficus religios or bodhi tree forests and the likes, because the word does not only mean Kunjara as elephants, but the name also refers to some trees species including the bodhi tree (Poesponegoro et al 2009; Wirasanti $2015 \& 2016)$. It is interesting that there is currently a toponym of hamlet using Gajahan word (Wirasanti, 2016).

Thus there are toponyms name of Gajahan and also Medangan. It is mentioned as well that Medang palace was located in Poh Pitu (mdang I poh pitu = Mantiyasih I inscription 907 AD). The place was believed to be the palace of the first name of the Ancient Mataram kingdom. Whether there was a connection between the name of Medangan hamlet with the word Medang as the location of the palace of the ancient Mataram needs the archaeological data to support that position. Toponyms Medang (Phoebe) in the Indonesian dictionary means a tall and big tree; the wood is used for making boards of a building. Medang word seems to be a kind of perennials that grows in the hills of Gendol, and there are a number of other perennials used to name the village like Canggal, Ngasem, Gambir, Sejong, Bendosari, Mantingan, Duwet, and Waru. The utilization of perennials is not only used for the building materials, but it is also used for making the material for a boat (canoe), and wood fiber. Canggal is the name of the tree (Neobaluncarpus heimi) which is used to make canoes. The hibiscus (Hibiscus tillaceus) bark is utilized its fibers to make rope, and clothing. Arjunawiwaha states that groups of $r s i$ wore the garments from tree bark and lived in the hermitage (wanasrama). In the Old Javanese Ramayana manuscript, it is also mentioned garments of bark (Santiko 1986; Poerbatjaraka 2010; Zoetmulder, 1982; Wirasanti 2015 \& 2016).
Other evidences which indicate that Canggal Temple area in the eighth century $\mathrm{AD}$ is the portrait of people's lives influenced by the Indian culture is a temple which was built at the tops of hills (Gendol Hills), statues, Lingga and Yoni (Inventory Der Hindoe Oudheiden, 1915). Some temples which are still traceable today are the temples at Mantingan Hill, Bobosan Hill, Gunung Sari Hill, and Pring Hill.

Historically, Mataram kingdom (Hinduism) was located in Central Java and Yogyakarta in the VIII-X century AD. In the middle of $\mathrm{X}$ century $\mathrm{AD}$, the political activity was moved to East Java. Archaeological evidence proves that until Majapahit ended around XV century AD, the people embraced Hinduism-Buddhism (Pigeaud, Th., 1960), and in the cultural history, it is known as the Hinduism-Buddhism kingdoms in Indonesia. When Majapahit kingdom ended, the history wrote the new era of Islamic kingdom.

Islam entering the archipelago was not at the same time. The archaeological evidences of XI and XIII century AD about Islam in East Java is still limited. Chinese script written by Ma-Huan around 1433 and the Portuguese script mainly written by Tome Pires (1512-1515) provide an overview of the presence of traders and mullahs in the port cities of the northern coastal of West Java, Central Java, and East Java. Islamization occurred in the northern coastal city of Java led to the emergence of Islamic kingdoms such as the kingdom of Demak followed by the kingdom located in inland area of Java such as Pajang and Mataram (Islam) (Graaf, HJ.de, 1952; Tjandrasasmita, 2009 \& ed, 2002).

There are a lot of different opinions dealing with the problems because of the arrival of Islam in Indonesia. Similarly, the process of Islamization in each region was also different. Regardless of the different opinions, Canggal Temple area became Muslim residential area with the tombs of prominent mullah of Islam as the evidences. People believed that the figures buried at the site were mullahs as the founder of the area.

The interesting phenomenon is that the tombs were built at the top of Gendol Hills complex which they are adjacent and even merge with the temple site. Most of the temples, accordingly, were converted to Islamic grave. In addition, there is a grave located on a hillside near Canggal Temple founded on the hilltop. Furthermore, there are also temples and tombs built on a hilltop which is closed to one another.

The phenomena of community identity changes occurred in Canggal Temple area are more appropriately called as cultural transformation which is a shift from one stage to another without changing the structure. Ahimsa-Putra (1999) argues that the meaning of transformation in structural analysis can be divided into a surface structure and deep structure. It means that the transformation in Canggal Temple area occurred in the surface layer, while the meaning did not change. Important aspects in discussing the transformation are acculturation and enculturation. 
TABLE I. CULTURAL TRANSFORMATION ANALYSIS OF STRUCTURES BASED ALERTS

\begin{tabular}{|c|c|c|c|c|c|}
\hline \multicolumn{3}{|c|}{ Environment Signifier } & \multicolumn{2}{|c|}{ Site Signifier } & Symbol (Signified) \\
\hline \multirow[b]{2}{*}{ Locations } & \multicolumn{2}{|c|}{\begin{tabular}{|l} 
toponym \\
\end{tabular}} & \multirow[b]{2}{*}{ Language } & \multirow[b]{2}{*}{ Categorization } & \multirow{13}{*}{$\begin{array}{l}\text { The concept of } \\
\text { sacred space }\end{array}$} \\
\hline & $\begin{array}{l}\text { Hinduism- } \\
\text { Buddhism } \\
\text { influence (Canggal } \\
\text { Inscription) }\end{array}$ & Islam Influence & & & \\
\hline Hill & Sthirangga & - & Sanskrit & $\begin{array}{l}\text { Mount Wukir } \\
\text { Temple }\end{array}$ & \\
\hline Hills and plains & $\begin{array}{l}\text { Kunjara Kunjadeca } \\
\text { (Kunjara Kunja } \\
\text { village) }\end{array}$ & - & Sanskrit & $\begin{array}{l}\text { Temples and statues } \\
\text { (meso area) }\end{array}$ & \\
\hline $\begin{array}{l}\text { A number of hills } \\
\text { and plains }\end{array}$ & $\begin{array}{l}\text { Javakhyam (Java } \\
\text { Island) }\end{array}$ & - & Sanskrit & $\begin{array}{l}\text { Temples and statues } \\
\text { (macro area) }\end{array}$ & \\
\hline Hill & Mantingan & - & Javanese (local) & Mantingan temple & \\
\hline Hill & Bobosan & - & Javanese (local) & Bobosan temple & \\
\hline Hill & - & Kadiluwih & Javanese (local) & $\begin{array}{l}\text { Tomb of Budo "Giri } \\
\text { Sentono" }\end{array}$ & \\
\hline Hill & - & Mantingan & Javanese (local) & $\begin{array}{l}\text { Tomb of Kyai } \\
\text { R.Sahid }\end{array}$ & \\
\hline Hill & - & Bobosan & Javanese (local) & $\begin{array}{l}\text { Tomb for Muslim } \\
\text { community }\end{array}$ & \\
\hline Plain & - & Kadiluwih & Javanese (local) & Tomb of Kyai Hajar & \\
\hline Plain & - & Kangkungan & Javanese (local) & $\begin{array}{l}\text { Tomb of Kyai Raden } \\
\text { Kangkung }\end{array}$ & \\
\hline Plain & - & Carikan & Javanese (local) & $\begin{array}{l}\text { Tomb of Kyai } \\
\text { Raden Jolosutro }\end{array}$ & \\
\hline
\end{tabular}

Based on structural analysis (sintagma-paradigma) (Table 1), it could be traced the acculturation process that occurred between the local cultures with the Indian culture (HinduismBuddhism) followed by Islamic culture. The entry of the Indian culture in the IV century AD brought some changes to the local culture, especially the religious aspects, namely worshipping for ancestral spirits. Before the entry of Indian culture to Archipelago, people worshipped their ancestors with media called punden berundak (shrine) which essentially represented a mountain (Soeyono, 1977). The analogy of the belief could be interpreted that there were two realms of lives, namely the place of humans to live and the realm of spirits. The spirits of dead people were located in "above". It was proven by the study of prehistoric skeleton positions (situs Gilimanuk-Bali, Situs Watu Kandang- Matesih) which were typically facing to the location of mountains; it showed the value of mountains in the cosmology perspective of people at that period.

The belief towards the mountains met with Hinduism cosmography; that mountains were dwelling places of the gods. Shiva dwelt in Gauri-Sangkar peak of Mount Everest. Both cosmographies had a meeting point that enabled acculturation happened (Abdullah, 2012). The community had the ability to deal with a foreign culture which was, then, adapted to local cultural identity and ultimately produce products that became characteristic of the present culture, so ultimately, it created a distinctive identity of local communities (Wales, 1949, Geldern, 1952., Koentjaraningrat, 1986). It meant that society's belief of the mountains as the dwelling place of the ancestors' spirits continued, and it, then, perceived as Stana (throne) of the gods. Thus, punden transformed into architecture which represented the mountain (Romond, 1951, Wirasanti, 2015). Mountain as the central symbol of the cosmos with the physical form towering up into the sky became the axis leading to the upper world, the spirit world. The concept of this belief became one of the reasons of the temple built on a hill.

In observing the temple site and its environment, it will be seen the way society in managing and selecting a room especially in selecting a sacred space was not random. Society has knowledge that the space has a value that is not the same; there are different spaces in the quality of the other. The space is not only understood on the physical realm, but a person or a community observes a variety of spaces of different values (Rapoport 1977, Dillistone 2006, Wirasanti,2016).

The phenomena in Canggal Temple area showed a shift of cultural identity from Hinduism culture using Sanskrit into Islamic settlement with local Javanese toponyms ( Mantingan, Bobosan, Kadiluwih, Kangkungan, Carikan) set in Arabic language. Islamic tombs located on hilltops, merging at the temple site or near the temple, proving that local communities still had the similar concept of belief with the previous periods. It could be interpreted that the high places (mountains, hills) were sacred spaces that presented transcendent things in the religious consciousness of society (Wirasanti, 2015). The toponyms which were selected were not only based on geographic phenomena, but they also used the name of respected mullahs ( Kyai Raden.Sahid, Kyai Hajar, Kyai Raden Kangkung, Kyai Raden Jolosutro) (Table $1)$.

\section{CONCLUSION}

Toponyms in Canggal Temple area presented the meaning of how people perceived and respect the environment as stipulated by the language. The conventional naming indicated the development of cultures of the society from the identity of Hinduism to the Islamic cultures. The phenomenon could be interpreted as a form of transition or a shift towards a certain culture without changing the structure although it was manifested in a new form.

\section{References}

Abdullah, Taufik, ed. (2012). Indonesia dalam arus sejarah. Jakarta, Kementrian Pendidikan dan Kebudayaan Indonesia.

Ahimsa-Putra, Heddy. (1999). Struktur simbolis budya Jawa. Yogyakarta: Balai Kajian Sejarah dan Nilai Tradisional.

Bernet-Kempers, A. J. (1959). Ancient Indonesian art. Amsterdam.

Dellistone, F.W. (2006) The power of symbol. Yogyakarta: Yayasan Kanisius.

Geldern, Heine, R. (1952). Conseptions of state and kingship in Southest Asia. Far Eastern Qarterly, II, 15-30. 
Graaf, H.J.de, (1952). "Tom pires suma oriental" en het tijdperk van goddienstovergang op Java, BKI,108,132171.

Koentjaraningrat. (1982). Peranan local genius dalam akulturasi, kepribadian budaya bangsa. Jakarta: Pustaka Jaya, p. 80-90.

Levi-Strauss,Claude. (2013). Antropologi structural. (Terj.). Yogyakarta: Kreasi Wacana.

Munoz, Paul Michel. (2009). Kerajaan-kerajaan awal kepulauan Indonesia dan Semenanjung Malaysia, perkembangan sejarah dan budaya Asia Tenggara (jaman pra sejarah - abad XVII). Yogyakarta: Penerbit Mitra Abadi.

Pigeaud,Th.G.Th. (1960). Java in the fourteen century: a study in cultural history the negarakertagama by Rakawi Prapanca of Majapahit,1365 A.D. The Hague: Martina Nijhoff,1960, M Bijhoff,1967.

Poerbotjaraka. (1982). Riwayat Indonesia I. Yayasan Pembangunan Jakarta.

Poesponegoro, Marwati Djoened dan Nugroho Notosusanto ed. (2009). Sejarah nasional Indonesia jilid II. Jakarta: Balai Pustaka.

Rapoport, Amos. (1977). Human aspek of urban form. Oxford, Toronto: Perganon Press.

Sedyawati, Edy. (1995). Pengarcaan Ganesya masa Kediri dan Singosari (Disertasi). LIPI

Soeyono. (1977). Sistem-sistem penguburan pada akhir masa prasejarah di Bali (Disertasi). Universitas Indonesia, Jakarta.
Tjandrasasmita, Uka. (2009). Arkeologi Islam nusantara. Jakarta: KPG (Kepustakaan Populer Gramedia). , ed. (2002). Sejarah nasional Indonesia zaman kuna. Jakarta: Balai Pustaka.

Romondt,V.R, van. (1951). Peninggalan purbakala di gunung Penanggungan. Jakarta: Dinas Purbakala RI.

Wirasanti, Niken. (2015). Lingkungan candi abad IX-X masehi masa Mataram kuna di poros Kedu SelatanPrambanan (Disertasi). Yogyakarta, Pasca Sarjana UGM.

Wirasanti, Niken, Helmi Murwanto. (2016). Rekonstruksi keruangan kompleks perbukitan Gendol-Kabupaten Magelang berdasar prasasti Canggal 732 Masehi (Laporan Penelitian). Yogyakarta, FIB-UGM.

Wales, Quaritch, H.G. (1948-1949). Culture change in greater India. Journal of the Royal Asiatic Society, 2-32.

Santiko, Hariani. (1986). Mandala pada masyarakat Majapahit, PIA IV: Jakarta, Puslit Arkenas, pp. 149-169.

Sedyawati, Edy. (1995). Pengarcaan Ganesya masa Kediri and Singosari (Disertasi). Jakarta, LIPI.

Zoetmulder, P. J. (1982). Old Javanese English dictionary, Gravenhage, Martinus Nijhoff.

Inventaris der Hindoe Oudheiden op den Grondslag van DR R.D.M verbeek's oudheden van Jawa. Bataviaasch Genootschap van Kunsten en wetenschapen. Alberchtt \& co Batavia 1915. 